\title{
Highly fractionated I-type granites in NE China (II): isotopic geochemistry and implications for crustal growth in the Phanerozoic
}

\author{
Fu-yuan $\mathrm{Wu}^{\mathrm{a}, \mathrm{b}}$, Bor-ming Jahn ${ }^{\mathrm{b}, *}$, Simon A. Wilde ${ }^{\mathrm{c}}$, Ching-Hua Lo ${ }^{\mathrm{d}}$, \\ Tzen-Fu Yui ${ }^{\mathrm{e}}$, Qiang Lin ${ }^{\mathrm{a}}$, Wen-chun $\mathrm{Ge}^{\mathrm{a}}$, De-you Sun ${ }^{\mathrm{a}}$ \\ ${ }^{a}$ Department of Geology, Jilin University, 79 Jianshejie, 130061 Changchun, China \\ ${ }^{\mathrm{b}}$ Géosciences Rennes (CNRS), Université de Rennes I, Avenue du Géneral Leclerc, 35042 Rennes cedex, France \\ ${ }^{\mathrm{c}}$ Department of Applied Geology, Curtin University of Technology, Perth, Western Australia 6845, Australia \\ d Department of Geology, National Taiwan University, 245 Choushan Road, Taipei, 10770, Taiwan, ROC \\ ${ }^{\mathrm{e}}$ Institute of Earth Sciences, Academia Sinica, P.B. Box 1-55, Nankang, Taipei 115, Taiwan, ROC
}

Received 13 December 2001; accepted 22 January 2003

\begin{abstract}
NE China is the easternmost part of the Central Asian Orogenic Belt (CAOB). The area is distinguished by widespread occurrence of Phanerozoic granitic rocks. In the companion paper (Part I), we established the Jurassic ages (184-137 Ma) for three granitic plutons: Xinhuatun, Lamashan and Yiershi. We also used geochemical data to argue that these rocks are highly fractionated I-type granites. In this paper, we present $\mathrm{Sr}-\mathrm{Nd}-\mathrm{O}$ isotope data of the three plutons and 32 additional samples to delineate the nature of their source, to determine the proportion of mantle to crustal components in the generation of the voluminous granitoids and to discuss crustal growth in the Phanerozoic.

Despite their difference in emplacement age, $\mathrm{Sr}-\mathrm{Nd}$ isotopic analyses reveal that these Jurassic granites have common isotopic characteristics. They all have low initial ${ }^{87} \mathrm{Sr} /{ }^{86} \mathrm{Sr}$ ratios $(0.7045 \pm 0.0015)$, positive $\varepsilon_{\mathrm{Nd}}(T)$ values $(+1.3$ to +2.8$)$, and young $\mathrm{Sm}-\mathrm{Nd}$ model ages $(720-840 \mathrm{Ma})$. These characteristics are indicative of juvenile nature for these granites. Other Late Paleozoic to Mesozoic granites in this region also show the same features. $\mathrm{Sr}-\mathrm{Nd}$ and oxygen isotopic data suggest that the magmatic evolution of the granites can be explained in terms of two-stage processes: (1) formation of parental magmas by melting of a relatively juvenile crust, which is probably a mixed lithology formed by pre-existing lower crust intruded or underplated by mantle-derived basaltic magma, and (2) extensive magmatic differentiation of the parental magmas in a slow cooling environment.

The widespread distribution of juvenile granitoids in NE China indicates a massive transfer of mantle material to the crust in a post-orogenic tectonic setting. Several recent studies have documented that juvenile granitoids of Paleozoic to Mesozoic ages are ubiquitous in the Central Asian Orogenic Belt, hence suggesting a significant growth of the continental crust in the Phanerozoic. (C) 2003 Elsevier Science B.V. All rights reserved.
\end{abstract}

Keywords: Granite; Nd-Sr isotopes; NE China; Central Asian Orogenic Belt (CAOB); Post-orogenic; Continental growth

* Corresponding author. Present address: Dept. of Geosciences, National Taiwan University, 245 Choushan Road, Taipei, 10617, Taiwan. Tel.: +886-2-2363-0231 (ext. 2378); fax: +886-2-2363-6095.

E-mail address: jahn@ccms.ntu.edu.tw (B. Jahn). 


\section{Introduction}

Granitic magmatism is a key to the development of the continental crust and underlying lithospheric mantle. The Central Asian Orogenic Belt (CAOB), otherwise known as the Altaid Tectonic Collage (Sengör et al., 1993), is now proven to be the most important site of juvenile crustal formation in the Phanerozoic (Sengör et al., 1993; Sengör and Natal'in, 1996a,b; Kovalenko et al., 1996; Han et al., 1997; Wu et al., 1998, 2000, 2002; Chen et al., 2000; Heinhorst et al., 2000; Hu et al., 2000; Jahn et al., 2000a,b,c, 2001; Jahn, 2002). Along with other juvenile terranes along the Pacific Coast, namely, the Canadian Cordilleran batholiths (Samson et al., 1989, 1991; Silver and Chappell, 1988), the Peninsular Range and the Sierra Nevada batholiths in the United States and Mexico (DePaolo, 1981, 1988; DePaolo et al., 1991), the Andean batholiths of South America (Kay and Rapela, 1990) and the Antarctic Peninsula batholith (Pankhurst et al., 1988), the issue of continental growth in the Phanerozoic has become an important topic of research in the past decade.

Northeastern China (NE China), together with the Altai Mountains in the west and the northern part of Inner Mongolia in the middle, constitute a gigantic southern belt of the CAOB. Recent studies indicate that these granites have very juvenile, mantle-dominated $\mathrm{Sr}-\mathrm{Nd}$ isotopic characteristics, hence suggesting a massive addition of new crust in this part of the world (Wu et al., 1998, 2000, 2001, 2002; Chen et al., 2000; Chen and Jahn, 2000a,b; Zhao et al., 2000; Jahn et al., 2000a,b,c; Jahn, 2002). Precisely because of this special significance, we have decided to conduct a more systematic isotopic and petrogenetic study on the granitic intrusions in NE China (Jahn et al., 2001; Wu et al., 2000, 2001, 2002).

In the companion paper (Wu et al., 2003), we determined the emplacement ages and cooling rates of three highly fractionated I-type granitic plutons using zircon $\mathrm{U}-\mathrm{Pb}, \mathrm{Rb}-\mathrm{Sr}$ and $\mathrm{Ar}-\mathrm{Ar}$ geochronometers. We also used major and trace element data to constrain their petrogenesis. In this paper, we present the results of $\mathrm{Sr}-\mathrm{Nd}-\mathrm{O}$ isotopic tracer study on these three plutons. These data are used to delineate the nature of their source, and to determine the proportion of mantle to crustal components in the generation of the voluminous granitoids. Finally, we discuss the problem of juvenile crustal growth during the Phanerozoic in conjunction with the new $\mathrm{Sr}-\mathrm{Nd}$ isotopic data obtained for additional 13 Mesozoic granitoids from the Songliao Block and 19 Silurian to Cretaceous diotitic to granitic rocks from the Xing'an Block. The geological background information can be found in the companion paper ( $\mathrm{Wu}$ et al., 2003).

\section{Analytical techniques and data presentation}

\subsection{Nd isotope analyses and model age calculation}

$\mathrm{Nd}$ isotopic data were obtained using the method described by Jahn et al. (1996). Mass analyses were performed using a 7-collector Finnigan MAT-262 mass spectrometer in dynamic mode. ${ }^{143} \mathrm{Nd} /{ }^{144} \mathrm{Nd}$ ratio were normalized against the value of ${ }^{146} \mathrm{Nd} /{ }^{144} \mathrm{Nd}=0.7219$. During the period of data acquisition, our internal Ames $\mathrm{Nd}$ standard gave ${ }^{143} \mathrm{Nd} /{ }^{144} \mathrm{Nd}=0.511966 \pm 7$ $(2 \sigma, n=20)$, which is equivalent to the La Jolla $\mathrm{Nd}$ standard of 0.511860 .

The notations of $\varepsilon_{\mathrm{Nd}}$ and $f_{\mathrm{Sm} / \mathrm{Nd}}$ are defined as:

$$
\begin{aligned}
\varepsilon_{\mathrm{Nd}}= & {\left[\left({ }^{143} \mathrm{Nd} /{ }^{144} \mathrm{Nd}\right)_{\mathrm{s}} /\left({ }^{143} \mathrm{Nd} /{ }^{144} \mathrm{Nd}\right)_{\mathrm{CHUR}}-1\right] } \\
& \times 10000 \\
f_{\mathrm{Sm} / \mathrm{Nd}} & =\left[\left({ }^{147} \mathrm{Sm} /{ }^{144} \mathrm{Nd}\right)_{\mathrm{s}} /\left({ }^{147} \mathrm{Sm} /{ }^{144} \mathrm{Nd}\right)_{\mathrm{CHUR}}\right]-1
\end{aligned}
$$

where $\mathrm{s}=$ sample, and $\left({ }^{143} \mathrm{Nd} /{ }^{144} \mathrm{Nd}\right)_{\mathrm{CHUR}}=0.512638$, and $\left({ }^{147} \mathrm{Sm} /{ }^{144} \mathrm{Nd}\right)_{\mathrm{CHUR}}=0.1967$. Single-stage depleted mantle $\mathrm{Sm}-\mathrm{Nd}$ model ages $\left(T_{\mathrm{DM}}\right)$ were calculated assuming a linear evolution of isotopic composition from $\varepsilon_{\mathrm{Nd}}(T)=0$ at $4.56 \mathrm{Ga}$ to +10 at the present time. The equation for the single-stage model age is:

$$
\begin{aligned}
T_{\mathrm{DM}}= & 1 / \lambda \ln \left\{1+\left[\left({ }^{143} \mathrm{Nd} /{ }^{144} \mathrm{Nd}\right)_{\mathrm{s}}-0.51315\right]\right. \\
& \left.\left./\left[\left({ }^{147} \mathrm{Sm} /{ }^{144} \mathrm{Nd}\right)_{\mathrm{s}}\right]-0.2137\right]\right\},
\end{aligned}
$$

where $\lambda=$ decay constants of ${ }^{147} \mathrm{Sm}=0.00654$ $\mathrm{Ga}^{-1} \cdot T_{\mathrm{DM}}$ ages of the same pluton may show a considerable range as a result of REE fractionation. This is best exemplified by the granites from the Xinhuatun 
pluton (Fig. 1). In order to circumvent such a problem, we also calculate two-stage $\mathrm{Nd}$ model ages $\left(T_{\mathrm{DM} 2}\right)$ using the same assumption as Keto and Jacobsen (1987):

$$
T_{\mathrm{DM} 2}=T_{\mathrm{DM} 1}-\left(T_{\mathrm{DM} 1-t}\right)\left(\left(f_{\mathrm{cc}}-f_{\mathrm{s}}\right) /\left(f_{\mathrm{cc}}-f_{\mathrm{DM}}\right)\right),
$$

where $f_{\mathrm{cc}}, f_{\mathrm{s}}, f_{\mathrm{DM}}=f_{\mathrm{Sm} / \mathrm{Nd}}$ values of the continental crust, sample and depleted mantle, respectively. In our calculation, $f_{\mathrm{cc}}=-0.4, f_{\mathrm{DM}}=0.0859$, and $t=$ intrusive age of granite.

In fact, the choice of single- or two-stage model (DePaolo et al., 1991) is difficult, as each model has its own pitfalls and uncertainties. For the single-stage model, the main uncertainties may result from: (1) $\mathrm{Sm} / \mathrm{Nd}$ fractionation between granitic melts and their sources during partial melting, (2) $\mathrm{Sm} / \mathrm{Nd}$ fractionation during magma differentiation, and (3) mixing of melts or sources in the petrogenetic processes (for more detailed discussion, see Arndt and Goldstein, 1987; Jahn et al., 1990). Many silica-rich granitoids in NE China show highly fractionated REE patterns, leading to enhanced $\mathrm{Nd} / \mathrm{Sm}$ ratios and reduced model ages. In such a case, single-stage model ages are evidently not meaningful. One way to «correct» the problem is to restrict the use of single-stage model ages to rocks with a limited range of $\mathrm{Sm} / \mathrm{Nd}$ fractionation, expressed as $f_{\mathrm{Sm} / \mathrm{Nd}}$ value, to the range of -0.2 to -0.6 . On the other hand, the two-stage model

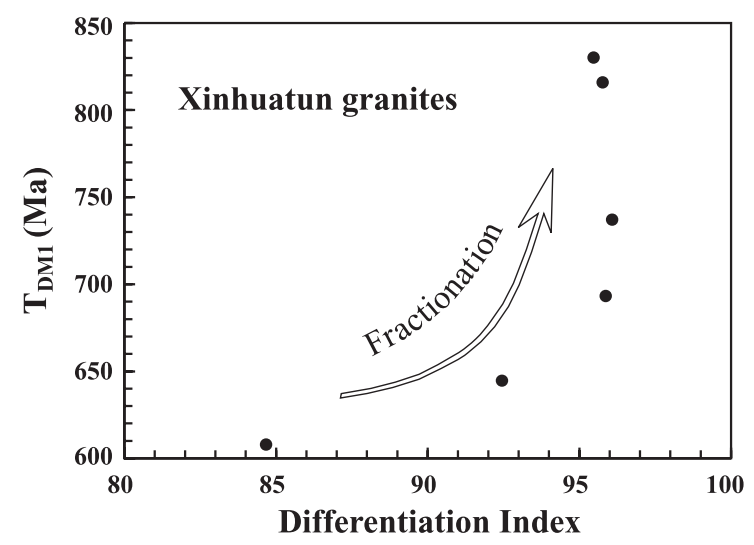

Fig. 1. Differentiation index (DI, sum of normative minerals $\mathrm{Q}+\mathrm{Ab}+\mathrm{Or})$ vs. single-stage model age $\left(T_{\mathrm{DM} 1}\right)$ diagram for the granites of the Xinhuatun pluton showing the effect of magmatic fractionation on calculated $T_{\mathrm{DM}}$. assumes that the sources of all granites follow the same isotope evolution as the average continental crust, regardless of their true lithological characteristics. If this model is adopted, we observe that most granitoid data would form a linear array in $\varepsilon_{\mathrm{Nd}}(T)$ vs. $T_{\mathrm{DM}}$ plots. The assumed uniform $\mathrm{Sm} / \mathrm{Nd}$ for all kinds of protoliths can hardly be proven true. Nevertheless, in order to utilize all our $\mathrm{Sm}-\mathrm{Nd}$ data, we chose to use $T_{\mathrm{DM} 2}$ in the following discussion.

\subsection{Oxygen isotope analyses}

Quartz and feldspar were separated and purified by magnetic separation and hand picking. The purity of all mineral separates was checked by X-ray diffraction, and is better than $95 \%$. Oxygen isotope analyses were performed on mineral separates and whole rock powders using the $\mathrm{BrF}_{5}$ procedures (Clayton and Mayeda, 1963). Isotope measurements were done on $\mathrm{CO}_{2}$ gas samples using a MAT 252 mass spectrometer at the Academia Sinica in Taiwan. The results are reported as conventional per mil $\delta^{18} \mathrm{O}$ values relative to SMOW. The reproducibility is better than $\pm 0.2 \%$. The mean value for the NBS-28 standard obtained during the present study was $+9.6 \%$.

\section{Isotopic constraints on granite petrogenesis}

$\mathrm{Rb}-\mathrm{Sr}$ isotopic data were given in Table 4 of the companion paper (Wu et al., 2003). It is shown that most initial ${ }^{87} \mathrm{Sr} /{ }^{86} \mathrm{Sr}$ ratios for low $\mathrm{Rb} / \mathrm{Sr}$ samples have a restricted range from 0.704 to 0.705 , which is rather low for granitic rocks formed in Phanerozoic orogenic belts, but is quite typical for the Phanerozoic granitoids of the CAOB (Kovalenko et al., 1996; Jahn et al., 2000a,b,c).

For the $\mathrm{Sm}-\mathrm{Nd}$ isotope data (Table 1), all samples have positive $\varepsilon_{\mathrm{Nd}}(T)$ values $(+2.5$ to +2.8 for Xinhuatun, +1.3 to +1.7 for Lamashan, and +1.9 to +2.5 for Yiershi) and very young depleted-mantle model ages $\left(T_{\mathrm{DM} 2}\right)$ ranging from 720 to $840 \mathrm{Ma}$ (except for enclave X-5). In contrast to the rocks of the Xinhuatun pluton, the granites of the Lamashan and Yiershi plutons have very low values of $f_{\mathrm{Sm} / \mathrm{Nd}}$ (down to -0.68). These values are much lower than that of the continental crust $(-0.40$; e.g., Jahn and Condie, 1995), and are likely produced by extensive 
Table 1

$\mathrm{Sm}-\mathrm{Nd}$ isotopic compositions of granites from three plutons in NE China

\begin{tabular}{|c|c|c|c|c|c|c|c|c|c|c|c|c|c|}
\hline & $\begin{array}{l}\text { Analysis } \\
\text { no. }\end{array}$ & $\begin{array}{l}\text { Sample } \\
\text { no. }\end{array}$ & $\begin{array}{l}\text { Age } \\
(\mathrm{Ma})\end{array}$ & $\begin{array}{l}\mathrm{Sm} \\
(\mathrm{ppm})\end{array}$ & $\begin{array}{l}\mathrm{Nd} \\
(\mathrm{ppm})\end{array}$ & $\begin{array}{l}{ }^{147} \mathrm{Sm} / \\
{ }^{144} \mathrm{Nd}\end{array}$ & $\begin{array}{l}{ }^{143} \mathrm{Nd} / \\
{ }^{144} \mathrm{Nd}\end{array}$ & $\pm 2 \sigma_{\mathrm{m}}$ & $\varepsilon_{\mathrm{Nd}}(0)$ & $\begin{array}{l}\varepsilon_{\mathrm{Nd}} \\
(T)\end{array}$ & $\begin{array}{l}T_{\mathrm{DM} 1} \\
(\mathrm{Ma})\end{array}$ & $\begin{array}{l}T_{\mathrm{DM} 2} \\
(\mathrm{Ma})\end{array}$ & $f_{\mathrm{Sm} / \mathrm{Nd}}$ \\
\hline \multirow[t]{7}{*}{ Xinhuatun } & 12970 & $X-1$ & 173 & 1.35 & 7.10 & 0.1152 & 0.512674 & 7 & 0.7 & 2.5 & 737 & 754 & -0.41 \\
\hline & 12971 & $\mathrm{X}-2$ & 173 & 3.62 & 22.29 & 0.0982 & 0.512662 & 9 & 0.5 & 2.6 & 645 & 742 & -0.50 \\
\hline & 12972 & $X-3$ & 173 & 2.47 & 13.39 & 0.1116 & 0.512686 & 6 & 0.9 & 2.8 & 693 & 728 & -0.43 \\
\hline & 12973 & X-4 & 173 & 6.42 & 41.67 & 0.0932 & 0.512670 & 7 & 0.6 & 2.9 & 608 & 721 & -0.53 \\
\hline & 12974 & $X-5$ & 173 & 4.60 & 19.13 & 0.1452 & 0.512688 & 8 & 1.0 & 2.1 & 1028 & 785 & -0.26 \\
\hline & 12975 & $X-6$ & 173 & 2.82 & 13.16 & 0.1296 & 0.512700 & 8 & 1.2 & 2.7 & 816 & 738 & -0.34 \\
\hline & 12976 & $X-7$ & 173 & 3.17 & 14.53 & 0.1317 & 0.512709 & 6 & 1.4 & 2.8 & 820 & 728 & -0.33 \\
\hline \multirow[t]{9}{*}{ Lamashan } & 12977 & L-1 & 154 & 3.82 & 23.05 & 0.1001 & 0.512625 & 6 & -0.3 & 1.6 & 705 & 808 & -0.49 \\
\hline & 12978 & $\mathrm{~L}-2$ & 154 & 3.47 & 20.76 & 0.1012 & 0.512616 & 8 & -0.4 & 1.4 & 724 & 824 & -0.49 \\
\hline & 12979 & L-3 & 154 & 3.64 & 21.50 & 0.1024 & 0.512615 & 7 & -0.4 & 1.4 & 733 & 828 & -0.48 \\
\hline & 12980 & $\mathrm{~L}-4$ & 154 & 1.93 & 13.37 & 0.0871 & 0.512607 & 7 & -0.6 & 1.6 & 654 & 816 & -0.56 \\
\hline & 12981 & L-5 & 154 & 1.65 & 11.72 & 0.0851 & 0.512601 & 7 & -0.7 & 1.5 & 651 & 823 & -0.57 \\
\hline & 12982 & L-6 & 154 & 1.96 & 14.24 & 0.0831 & 0.512591 & 7 & -0.9 & 1.3 & 653 & 835 & -0.58 \\
\hline & 12983 & L-7 & 154 & 1.74 & 12.50 & 0.0840 & 0.512606 & 7 & -0.6 & 1.6 & 640 & 813 & -0.57 \\
\hline & 12984 & L-8 & 154 & 1.06 & 7.77 & 0.0828 & 0.512597 & 7 & -0.8 & 1.4 & 645 & 825 & -0.58 \\
\hline & 12985 & L-9 & 154 & 0.89 & 6.92 & 0.0782 & 0.512583 & 7 & -1.1 & 1.3 & 638 & 840 & -0.60 \\
\hline \multirow[t]{9}{*}{ Yiershi } & 12986 & YE-1 & 143 & 3.31 & 19.94 & 0.1004 & 0.512642 & 7 & 0.1 & 1.8 & 684 & 784 & -0.49 \\
\hline & 12987 & YE-2 & 143 & 1.94 & 13.41 & 0.0875 & 0.512649 & 7 & 0.2 & 2.2 & 606 & 754 & -0.56 \\
\hline & 12988 & YE-3 & 143 & 3.57 & 22.41 & 0.0963 & 0.512670 & 7 & 0.6 & 2.5 & 624 & 733 & -0.51 \\
\hline & 12989 & YE-4 & 143 & 3.31 & 20.71 & 0.0967 & 0.512660 & 6 & 0.4 & 2.3 & 639 & 750 & -0.51 \\
\hline & 12990 & YE-5 & 143 & 4.16 & 23.81 & 0.1056 & 0.512677 & 7 & 0.8 & 2.4 & 668 & 736 & -0.46 \\
\hline & 12991 & YE-6 & 143 & 0.24 & 2.30 & 0.0636 & 0.512618 & 7 & -0.4 & 2.0 & 541 & 768 & -0.68 \\
\hline & 12992 & YE-7 & 143 & 0.25 & 2.06 & 0.0746 & 0.512619 & 7 & -0.4 & 1.9 & 583 & 782 & -0.62 \\
\hline & 12993 & YE-8 & 143 & 2.30 & 15.34 & 0.0906 & 0.512640 & 7 & 0.0 & 2.0 & 632 & 773 & -0.54 \\
\hline & 12974 & YE-9 & 143 & 2.62 & 15.07 & 0.1050 & 0.512663 & 8 & 0.5 & 2.2 & 684 & 757 & -0.47 \\
\hline
\end{tabular}

fractional crystallization involving high $\mathrm{Sm} / \mathrm{Nd}$ accessory minerals, such as apatite, titanite and hornblende.

To account for the petrogenesis of these highly fractionated I-type granites, several processes can be envisaged: (a) differentiation of mantle-derived mafic magma; (b) partial melting of a mixed source rock produced by intercalation of underplated mafic magma in lower crustal rocks, and (c) mixing of mantle- and crustally derived magmas, which, in turn, underwent fractional crystallization. Here we use Sr, $\mathrm{Nd}$ and oxygen isotope tracers to assess the different petrogenetic processes.

\subsection{Sr-Nd isotopic constraint}

As just mentioned, the most striking feature for the granites of NE China is their low $\left({ }^{87} \mathrm{Sr} /{ }^{86} \mathrm{Sr}\right)_{\mathrm{i}}$, positive $\varepsilon_{\mathrm{Nd}}(T)$ values, and young $\mathrm{Sm}-\mathrm{Nd} T_{\mathrm{DM} 2}$ ages (mainly $720-840 \mathrm{Ma}$ ) (Fig. 2). In order to provide a more generalized picture for NE China, we further analyzed
32 additional granitoid samples for their $\mathrm{Sr}-\mathrm{Nd}$ isotopic compositions. The localities of these samples can be identified in a later section (Fig. 7). The new data are presented in Table 2.

In the Songliao Block, most of the granites were emplaced during Late Triassic to Middle Jurassic, and all of them have low $\left({ }^{87} \mathrm{Sr} /{ }^{86} \mathrm{Sr}\right)_{\mathrm{i}}$ ratios (ca. $0.705)$ and positive $\varepsilon_{\mathrm{Nd}}(T)$ values $(0$ to +4$)$ except the Renao pluton situated in the south of Changchun in Jilin province. By contrast, the granites in the Xing'an Block show a larger range of emplacement ages from 430 to $110 \mathrm{Ma}$. The Silurian Tafeng pluton located in the northern part show negative $\varepsilon_{\mathrm{Nd}}(T)$ values $(-1.6$ to -4.5$)$ and slightly higher $\left({ }^{87} \mathrm{Sr} /{ }^{86} \mathrm{Sr}\right)_{\mathrm{i}}$ ratios of $0.705-0.708$ (except a high $\mathrm{Rb} / \mathrm{Sr}$ granite), but the Permian to Mesozoic granites have the same $\mathrm{Sr}-\mathrm{Nd}$ isotopic features as those in the Songliao Block.

In summary, the granites from different blocks of NE China display almost the same $\mathrm{Sr}-\mathrm{Nd}$ isotopic 

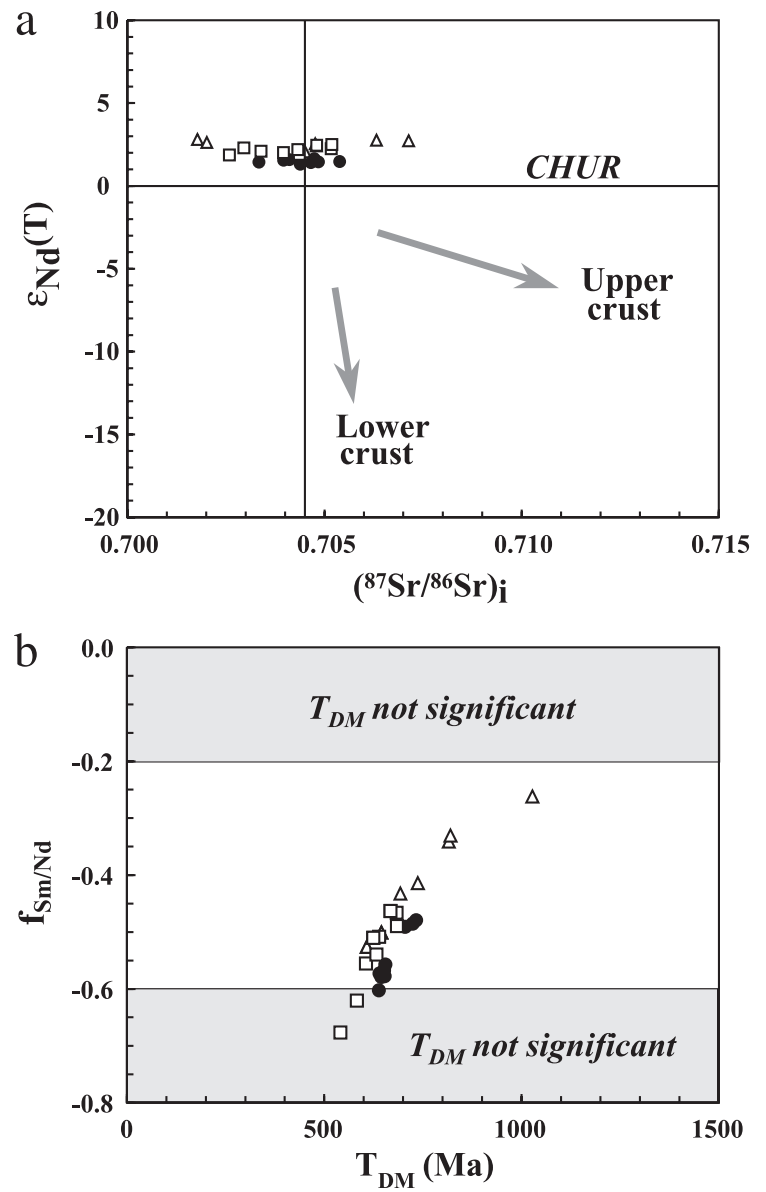

Fig. 2. (a) $\varepsilon_{\mathrm{Nd}}(T)$ vs. $\left({ }^{87} \mathrm{Sr} /{ }^{86} \mathrm{Sr}\right)_{\mathrm{i}}$ diagram for the granites of the Xinhuatun (open triangles), Lamashan (solid circles) and Yiershi (open squares) plutons. (b) $f_{\mathrm{Sm} / \mathrm{Nd}}$ vs. $T_{\mathrm{DM}}$ diagrams showing young $\mathrm{Sm}-\mathrm{Nd}$ model ages $(500-1000 \mathrm{Ma})$. Rocks with very low $f_{\mathrm{Sm} / \mathrm{Nd}}$ values $(<-0.6)$ or «high» $f_{\mathrm{Sm} / \mathrm{Nd}}$ values $(>-0.2)$ may result in unrealistic model ages. More meaningful model ages are found with $f_{\mathrm{Sm} / \mathrm{Nd}}$ values in the range of $-0.4 \pm 0.2$ (in the white zone).

characters except the Silurian Tafeng pluton. The results suggest a high proportion of mantle-derived material in the generation of these granitoids. In order to estimate the proportion of mantle-to-crust component, a simple mixing model was employed, and the result of mixing calculation using $\mathrm{Sr}-\mathrm{Nd}$ isotopic data is shown in Fig. 3. The proportion of the mantle component using $\mathrm{Nd}$ isotope data alone is illustrated in Fig. 4. Fig. 3 shows that the upper crustal component (UCC) has little or no role in the generation of the granites; whereas mantle-derived basaltic magma and the lower crust (LCC) are the two major components. In both Figs. 3 and 4, the mantle component represents about $60-90 \%$. This by no means indicates that the granites were formed by mixing basaltic and lower crustal melts in such proportions. Rather, it suggests that the granitic magmas were produced by melting of a mixed lithology containing a lower crustal gneiss intruded or underplated by a basaltic magma in such a proportion $(60-90 \%)$ for the latter.

Fig. 4 shows that the granites from the Songliao Block contain about $80-90 \%$ of juvenile crust, and those from the Xing'an Block are about $60-90 \%$. Apparently, the granites from the Songliao Block have a higher proportion of the mantle component that those from the Xing'an Block. This point is in fact consistent with the oxygen isotopic data to be presented below. In any case, it could be concluded that juvenile crust is the major protolith for the granites in NE China.

\subsection{Oxygen isotopic constraint}

$\delta^{18} \mathrm{O}$ data for whole-rock, quartz and feldspar samples of the three plutons are given in Table 3. In all cases, whole-rock and feldspar data show a greater variation in O-isotope composition than quartz. Two whole rock and four feldspar samples even have negative $\delta^{18} \mathrm{O}$ values. Under equilibrium conditions, the $\mathrm{O}$-isotope fractionation between quartz and feldspar should fall in the range of $0.5-2.0 \%$ at magmatic temperatures (Chiba et al., 1989). However, the $\Delta^{18} \mathrm{O}$ (quartz-feldspar) values range from -1.3 to $+3.7 \%$, -0.4 to $+11.7 \%$, and +1.1 to $+12.7 \%$ o for the Xinhuatun, Lamashan, and Yiershi plutons, respectively, indicating that the $\mathrm{O}$ isotopes did not reach equilibrium in all samples. Isotopic disequilibrium among minerals is not uncommon in granites. The present isotopic characteristics demonstrate that the three plutons have experienced post-emplacement open-system hydrothermal alteration (Gregory and Criss, 1986; Gregory et al., 1989). Meteoric water was the most probable fluid involved in the water-rock interactions for these granitic intrusions.

In a $\delta^{18} \mathrm{O}$ (feldspar) vs. $\delta^{18} \mathrm{O}$ (quartz) diagram (Fig. 5), following Gregory and Criss (1986) and Gregory et al. (1989), two diagonal lines denote the probable 
Table 2

Additional $\mathrm{Sr}-\mathrm{Nd}$ isotopic data of granitoids from NE China

\begin{tabular}{|c|c|c|c|c|c|c|c|c|c|c|c|c|c|c|c|c|c|c|c|c|}
\hline Sample no. & Order & Pluton & Rock type & $\begin{array}{l}\text { Age } \\
\text { (Ma) }\end{array}$ & $\begin{array}{l}\mathrm{Rb} \\
\text { (ppm) }\end{array}$ & $\begin{array}{l}\mathrm{Sr} \\
(\mathrm{ppm})\end{array}$ & $\begin{array}{l}{ }^{87} \mathrm{Rb} / \\
{ }^{86} \mathrm{Sr}\end{array}$ & ${ }^{87} \mathrm{Sr} /{ }^{86} \mathrm{Sr}$ & $2 \sigma_{\mathrm{m}}$ & $I_{\mathrm{Sr}}$ & $\begin{array}{l}\text { Sm } \\
(\mathrm{ppm})\end{array}$ & $\begin{array}{l}\mathrm{Nd} \\
(\mathrm{ppm})\end{array}$ & $\begin{array}{l}{ }^{147} \mathrm{Sm} / \\
{ }^{144} \mathrm{Nd}\end{array}$ & $\begin{array}{l}{ }^{143} \mathrm{Nd} / \\
{ }^{144} \mathrm{Nd}\end{array}$ & $2 \sigma_{\mathrm{m}}$ & $\begin{array}{l}T_{\mathrm{DM} 1} \\
\text { (Ma) }\end{array}$ & $\begin{array}{l}T_{\mathrm{DM} 2} \\
(\mathrm{Ma})\end{array}$ & $\begin{array}{l}\varepsilon_{\mathrm{Nd}} \\
(T)\end{array}$ & $f_{\mathrm{Sm} / \mathrm{Nd}}$ & Lab.* \\
\hline \multicolumn{21}{|c|}{ Songliao Block } \\
\hline Heng-1 & 1 & Hengdaohezi & Monzogranite & 187 & 79.8 & 386.7 & 0.597 & 0.706906 & 20 & 0.7053 & 1.81 & 10.10 & 0.1083 & 0.512660 & 9 & 709 & 762 & 2.5 & -0.45 & $\mathrm{~b}$ \\
\hline $\mathrm{H}-7$ & 1 & Hengdaohezi & Monzogranite & 187 & 126.1 & 88.7 & 4.116 & 0.716097 & 6 & 0.7052 & 1.76 & 10.17 & 0.1046 & 0.512732 & 10 & 585 & 641 & 4.0 & -0.47 & $\mathrm{c}$ \\
\hline $9501-1$ & 2 & Shimeng & Granodiorite & 182 & 79.5 & 476.2 & 0.483 & 0.705876 & 13 & 0.7046 & 3.97 & 19.37 & 0.1239 & 0.512544 & 10 & 1029 & 976 & -0.1 & -0.37 & b \\
\hline $97103-1$ & 3 & Yima & Q diorite & 164 & 82.1 & 537.9 & 0.442 & 0.705901 & 23 & 0.7049 & 3.48 & 18.06 & 0.1164 & 0.512642 & 12 & 796 & 807 & 1.8 & -0.41 & a \\
\hline $97103-2$ & 3 & Yima (Enclave) & Diorite & 164 & 84.1 & 422.8 & 0.576 & 0.706151 & 17 & 0.7048 & 7.09 & 31.95 & 0.1341 & 0.512603 & 7 & 1047 & 899 & 0.6 & -0.32 & a \\
\hline SCS02-1 & 4 & Shancheshan & Q diorite & 164 & 54.9 & 573.7 & 0.277 & 0.705438 & 14 & 0.7048 & 3.64 & 17.81 & 0.1237 & 0.512574 & 7 & 975 & 927 & 0.3 & -0.37 & a \\
\hline SLS01-1 & 5 & Silengshan & Kf-granite & 290 & 205.6 & 4.89 & 127.9 & 1.234880 & 60 & 0.7070 & 14.00 & 50.13 & 0.1688 & 0.512697 & 7 & 1536 & 874 & 2.2 & -0.14 & a \\
\hline 9908-1 & 7 & Renao & Granodiorite & 180 & 91.7 & 658.2 & 0.403 & 0.706613 & 11 & 0.7056 & 2.65 & 17.29 & 0.0927 & 0.512368 & 8 & 985 & 1198 & -2.9 & -0.53 & a \\
\hline 9908-1 & 7 & Renao & Duplicate & 180 & & & & & & & 2.41 & 15.24 & 0.0957 & 0.512487 & 9 & 857 & 1015 & -0.6 & -0.51 & a \\
\hline 9909-3 & 8 & Xiangshuiyuanzi & Kf-granite & 180 & 359.2 & 6.06 & 178.9 & 1.152200 & 20 & 0.6944 & 4.51 & 12.77 & 0.2133 & 0.512675 & 9 & & 179 & 0.3 & 0.08 & a \\
\hline 9923-1 & 9 & Dayushan & Monzogranite & 248 & 72.6 & 790.5 & 0.266 & 0.705402 & 9 & 0.7045 & 2.73 & 16.66 & 0.0990 & 0.512599 & 9 & 732 & 829 & 2.3 & -0.50 & a \\
\hline \multicolumn{21}{|c|}{ Xing'an Block } \\
\hline $9808-1$ & 10 & Huaduoshan & Granodiorite & 170 & 63.1 & 492.6 & 0.371 & 0.705021 & 10 & 0.7041 & 3.63 & 20.18 & 0.1088 & 0.512721 & 6 & 624 & 668 & 3.5 & -0.45 & $\mathrm{a}$ \\
\hline 9825-1 & 11 & Tafeng & Adamellite & 430 & 125.0 & 324.4 & 1.116 & 0.714856 & 15 & 0.7080 & 6.12 & 40.21 & 0.0920 & 0.512141 & 8 & 1263 & 1489 & -3.9 & -0.53 & a \\
\hline 9825-3 & 11 & Tafeng & Granite & 430 & 182.2 & 22.03 & 24.28 & 0.858320 & 26 & 0.7096 & 8.57 & 24.72 & 0.2096 & 0.512446 & 7 & & 412 & -4.5 & 0.07 & a \\
\hline 9825-3 & 11 & Tafeng & Duplicate & 430 & 190.1 & 21.02 & 26.57 & 0.866007 & 15 & 0.7033 & & & & & & & & & & a \\
\hline 9825-4 & 11 & Tafeng & Diorite & 430 & 160.9 & 291.2 & 1.600 & 0.717419 & 14 & 0.7076 & 3.53 & 16.26 & 0.1311 & 0.51224 & 9 & 1676 & 1505 & -4.2 & -0.33 & a \\
\hline $9825-12$ & 11 & Tafeng & Diorite & 430 & 40.2 & 978.6 & 0.119 & 0.706157 & 20 & 0.7054 & 5.21 & 38.36 & 0.0821 & 0.512233 & 8 & 1062 & 1299 & -1.6 & -0.58 & a \\
\hline $9825-13$ & 11 & Tafeng & $\mathrm{Q}$ diorite & 430 & 70.5 & 777.9 & 0.262 & 0.708368 & 16 & 0.7068 & 5.46 & 28.73 & 0.1149 & 0.512227 & 12 & 1422 & 1454 & -3.5 & -0.42 & a \\
\hline $9825-14$ & 11 & Tafeng & $\mathrm{Q}$ diorite & 430 & 55.4 & 684.2 & 0.234 & 0.707702 & 15 & 0.7063 & 4.20 & 22.72 & 0.1117 & 0.512227 & 12 & 1378 & 1440 & -3.4 & -0.43 & a \\
\hline $9828-1$ & 12 & Xinghua & Adamellite & 110 & 83.0 & 545.9 & 0.440 & 0.704919 & 16 & 0.7042 & 5.63 & 27.73 & 0.1228 & 0.512719 & 18 & 723 & 693 & 2.6 & -0.38 & a \\
\hline $9828-1$ & 12 & Xinghua & Duplicate & 110 & 55.1 & 531.6 & 0.300 & 0.704911 & 16 & 0.7044 & & & & & & & & & & a \\
\hline 9831-1 & 13 & Baishilazi & Tonalite & 130 & 30.9 & 431.2 & 0.207 & 0.705746 & 14 & 0.7054 & 7.62 & 44.55 & 0.1034 & 0.512547 & 8 & 834 & 941 & -0.2 & -0.47 & a \\
\hline 9834-1 & 14 & Heihe & Adamellite & 280 & 174.9 & 181.7 & 2.788 & 0.717336 & 14 & 0.7062 & 5.89 & 26.32 & 0.1352 & 0.512499 & 7 & 1263 & 1086 & -0.5 & -0.31 & a \\
\hline 9836-1 & 15 & Datoushan & Adamellite & 120 & 90.6 & 542.0 & 0.483 & 0.706327 & 15 & 0.7055 & 4.63 & 26.66 & 0.1049 & 0.512492 & 8 & 922 & 1032 & -1.4 & -0.47 & a \\
\hline 9436-3 & 16 & Boketou & Tonalite & 156 & 92.8 & 710.6 & 0.378 & 0.706288 & 18 & 0.7055 & 5.07 & 25.01 & 0.1226 & 0.512587 & 8 & 942 & 904 & 0.5 & -0.38 & $\mathrm{~b}$ \\
\hline 9485-3 & 17 & Alihe & Kf-granite & 120 & 148.4 & 45.23 & 9.507 & 0.722484 & 20 & 0.7063 & 3.94 & 19.06 & 0.1249 & 0.512712 & 10 & 752 & 707 & 2.5 & -0.37 & b \\
\hline S-7 & 17 & Alihe & Kf-granite & 120 & 148.7 & 26.65 & 16.18 & 0.733327 & 6 & 0.7057 & 2.56 & 13.50 & 0.1146 & 0.512610 & 3 & 831 & 856 & 0.7 & -0.42 & c \\
\hline YL-7 & 18 & Yalu & Kf-granite & 140 & 175.0 & 94.18 & 5.380 & 0.715710 & 6 & 0.7050 & 4.60 & 24.47 & 0.1136 & 0.512625 & 6 & 800 & 830 & 1.2 & -0.42 & $\mathrm{c}$ \\
\hline YL-8 & 18 & Yalu & Kf-granite & 140 & 178.1 & 88.46 & 5.830 & 0.716713 & 7 & 0.7051 & 4.05 & 24.52 & 0.0999 & 0.512708 & 6 & 593 & 679 & 3.1 & -0.49 & c \\
\hline
\end{tabular}

* (a) Institute of Geology and Geophysics, Chinese Academy of Sciences; (b) Institute of Geology, Chinese Academy of Geological Sciences; (c) Geosciences Rennes, University of Rennes I. 


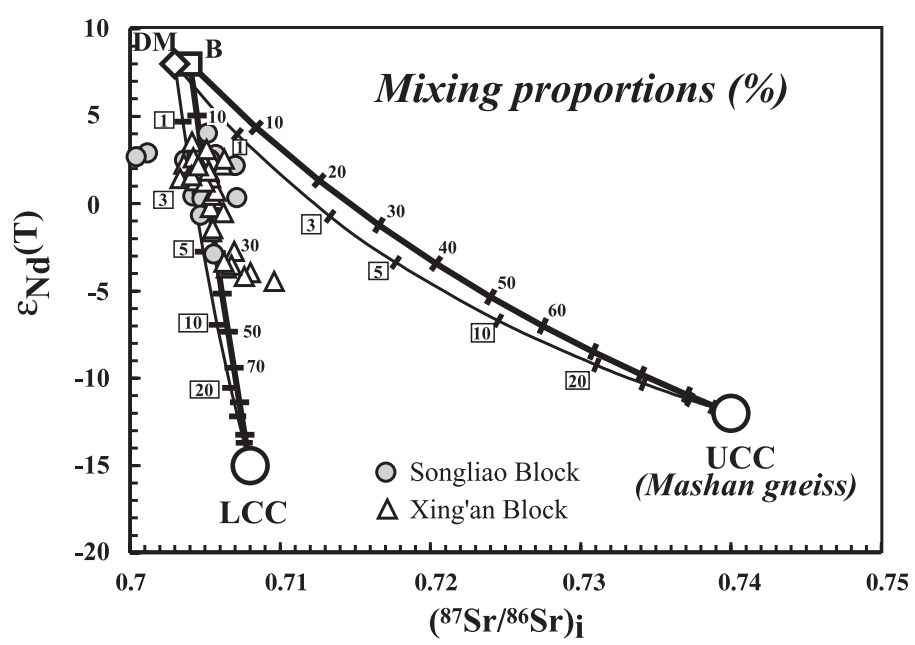

Fig. 3. $\varepsilon_{\mathrm{Nd}} \mathrm{Vs}{ }^{87} \mathrm{Sr} /{ }^{86} \mathrm{Sr}$ isotopic ratio plot showing mixing proportions between two end-members: (1) depleted mantle or juvenile components $(\mathrm{DM}=$ upper mantle peridotite; or $\mathrm{B}=$ basalt $)$ and $(2)$ crustal components $(\mathrm{LCC}=$ lower continental crust; or UCC $=$ upper continental crust, both of them are represented by the Mashan Group gneisses in the Jiamusi Block, see detail explanation in Wu et al., 2000). The parameters used are:

\begin{tabular}{lccrr}
\hline & DM & Basalt & UCC & LCC \\
\hline${ }^{87} \mathrm{Sr}{ }^{86} \mathrm{Sr}$ & 0.703 & 0.704 & 0.740 & 0.708 \\
{$[\mathrm{Sr}] \mathrm{ppm}$} & 20 & 200 & 250 & 230 \\
$\varepsilon_{\mathrm{Nd}}$ & +8 & +8 & -12 & -15 \\
{$[\mathrm{Nd}] \mathrm{ppm}$} & 1.2 & 15 & 30 & 20 \\
\hline
\end{tabular}

equilibrium isotopic fractionation between quartz and feldspar at magmatic temperatures. Most data points of the Lamashan and Xinhuatun plutons fall below or above the equilibrium range. This isotopic disequilibrium is mainly due to the fact that feldspar exchanges oxygen isotopes with the fluid more readily than quartz during water-rock interaction. The data points for the Lamashan granites form a steep array, most of them below the equilibrium range, whereas those for Xinhuatun spread in an S-shape outside of the equilibrium range. The distribution and shape of such data arrays are a function of several parameters: O-isotope composition of the fluid, water-rock ratio, temperature, difference of reaction rate of minerals and time duration of water-rock interactions (Gregory et al., 1989). The different arrays between the Lamashan and Xinhuatun plutons, however, indicate that the O-isotope system in the latter is closer to the equilibrium conditions. The intersections of the disequilibrium arrays with the equilibrium fractionation lines yield $\delta^{18} \mathrm{O}$ values (quartz) from +6.3 to $+6.8 \%$ for
Xinhuatun and +8.2 to $+8.7 \%$ for Lamashan, respectively (Fig. 5). These values probably are close to the primary magmatic $\delta^{18} \mathrm{O}$ of quartz for these two plutons.

Similarly, in a detailed study of stable isotopes of anorogenic granitoids from Transbaikalia, Wickham et al. (1996) found that most samples older than Early Permian show «normal» equilibrium fractionations with $\Delta_{\mathrm{Q}-\mathrm{Fd}}$ between 0.5 and 2.5. However, disequilibrium fractionation is found in samples of Permo-Triassic and Mesozoic plutons, which define fields with steep slopes that cross-cut the equilibrium fractionation lines at high angles, similar to the Lamashan granites (Fig. 5). These systematics are typical of plutonic rocks subjected to meteorichydrothermal alteration (e.g., Criss and Taylor, 1986). Unlike the Lamashan and Xinhuatun granites, the isotopic compositions of the Yiershi samples (except YE-1) fall close to the equilibrium lines at magmatic temperatures (Fig. 5). Their $\delta^{18} \mathrm{O}$ values might therefore be primary. A single feldspar (sam- 


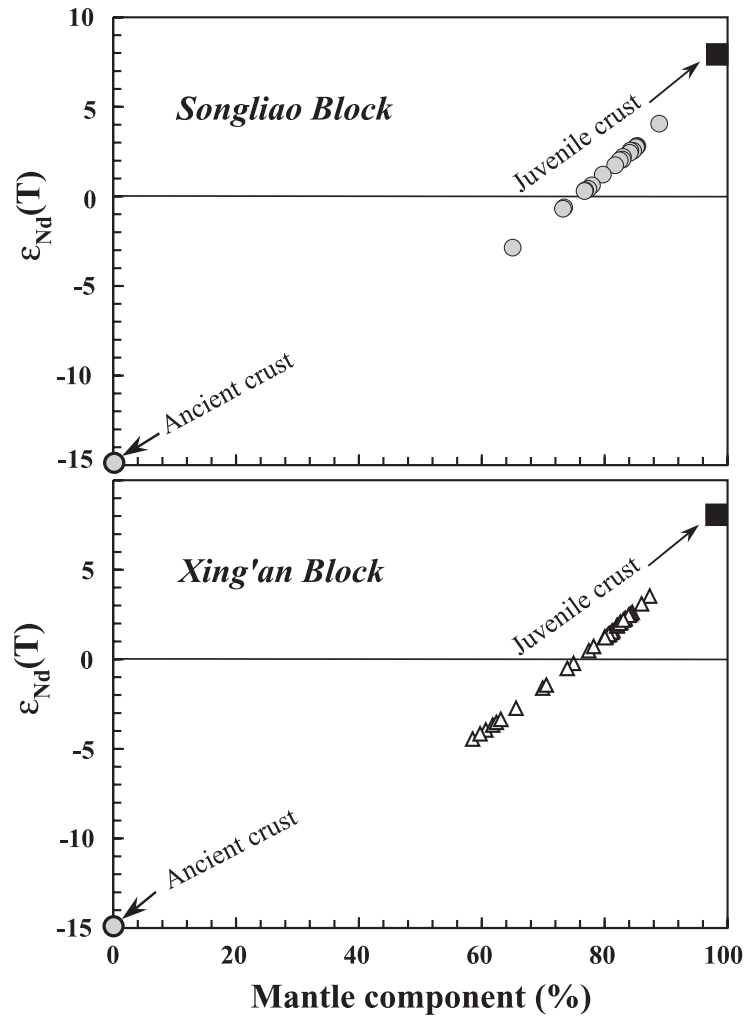

Fig. 4. Estimated proportions of the mantle or juvenile component for the granites from NE China. The equation is $x_{\mathrm{m}}=\left(\mathrm{Nd}_{\mathrm{c}} / \mathrm{Nd}_{\mathrm{m}}\right) /$ $\left(\left(\mathrm{Nd}_{\mathrm{c}} / \mathrm{Nd}_{\mathrm{m}}\right)+\left(\varepsilon_{\mathrm{m}}-\varepsilon_{\mathrm{s}}\right) /\left(\varepsilon_{\mathrm{s}}-\varepsilon_{\mathrm{c}}\right)\right)$ (DePaolo et al., 1991), where $x_{\mathrm{m}}=\%$ mantle component (represent by basalt). $\mathrm{Nd}_{\mathrm{c}}, \mathrm{Nd}_{\mathrm{m}}=\mathrm{Nd}$ concentrations in the crust and mantle components, respectively. $\varepsilon_{\mathrm{m}}, \varepsilon_{\mathrm{s}}$ and $\varepsilon_{\mathrm{c}}=\mathrm{Nd}$ isotopic compositions of the mantle or juvenile crust, samples measured, and crustal component, respectively. Parameters used: $\varepsilon_{\mathrm{m}}=+8, \varepsilon_{\mathrm{c}}=-15 . \mathrm{Nd}_{\mathrm{c}}=25 \mathrm{ppm}, \mathrm{Nd}_{\mathrm{m}}=15 \mathrm{ppm}$.

ple YE-1, Fig. 5), however, has negative O-isotope composition and is clearly not in isotopic equilibrium with the coexisting quartz, a situation similar to some Lamashan samples. Nevertheless, the present dataset demonstrates that meteoric waterrock interaction for the Yiershi granites was rather restricted in space during hydrothermal alteration. Note that the $\delta^{18} \mathrm{O}$ values of quartz and feldspar (except YE-1) range from +7.3 to $+10.1 \%$ and from +6.0 to $+9.4 \%$, respectively. Although these ranges are normal for granitic rocks, they are too large to be accounted for by simple magmatic differentiation considering that the modal compositions of quartz and feldspar (in Table 1; Wu et al.,
2003) in these samples are similar (Sheppard, 1986) Assimilation of country rocks during magma emplacement might have played an important role and the O-isotopes would not have been completely homogenized during assimilation and subsequent magmatic processes.

Therefore, the $\mathrm{O}$ isotopic data suggest that these granites from NE China did not come directly from the mantle but from a juvenile crust or a mantlederived magma that had been contaminated by a preexisting crustal component. It is also shown that the Xinhuatun granites from the Songliao Block have lower $\delta^{18} \mathrm{O}$ values than the Lamashan and Yiershi granites in the Xing'an Block, which might indicate that the Xinhuatun contains more juvenile components than the latter. This is generally consistent with

Table 3

Oxygen isotope data (in \%o, relative to SMOW)

\begin{tabular}{|c|c|c|c|c|}
\hline Sample no. & Whole-rock & Quartz & Feldspar & $\Delta(\mathrm{Q}-\mathrm{Fd})$ \\
\hline \multicolumn{5}{|l|}{ Xinhuatun } \\
\hline $\mathrm{X}-1$ & 7.6 & 6.6 & 7.9 & -1.3 \\
\hline $\mathrm{X}-2$ & 5.4 & 6.5 & 4.2 & 2.3 \\
\hline$X-3$ & 2.0 & 5.8 & 2.1 & 3.7 \\
\hline$X-4$ & 3.7 & 6.0 & 2.7 & 3.3 \\
\hline$X-5$ & 0.7 & 4.9 & 1.9 & 3.0 \\
\hline$X-6$ & 7.8 & 7.6 & 8.5 & -0.9 \\
\hline$X-7$ & 6.9 & 6.8 & 8.5 & -1.7 \\
\hline \multicolumn{5}{|l|}{ Lamashan } \\
\hline L-1 & -0.4 & 7.3 & -5.4 & 12.7 \\
\hline L-2 & 1.8 & 8.1 & -1.9 & 10.0 \\
\hline L-3 & 5.0 & 7.9 & 2.7 & 5.2 \\
\hline L-4 & 6.4 & 8.7 & 6.1 & 2.6 \\
\hline L-5 & 6.9 & 8.6 & 7.5 & 1.1 \\
\hline L-6 & 4.0 & 8.3 & 2.4 & 5.9 \\
\hline L-7 & 6.8 & 8.6 & 7.2 & 1.4 \\
\hline L-8 & 1.6 & 8.2 & -0.7 & 8.9 \\
\hline L-9 & 3.0 & 8.7 & 1.2 & 7.5 \\
\hline \multicolumn{5}{|l|}{ Yiershi } \\
\hline YE-1 & -1.6 & 6.7 & -5.0 & 11.7 \\
\hline YE-2 & 8.1 & 8.0 & 8.4 & -0.4 \\
\hline YE-3 & 8.4 & 8.9 & 7.6 & 1.3 \\
\hline YE-4 & 8.5 & 8.9 & 7.7 & 1.2 \\
\hline YE-5 & 8.6 & 8.9 & 8.6 & 0.3 \\
\hline YE-6 & 9.2 & 9.4 & 9.3 & 0.1 \\
\hline YE-7 & 9.7 & 10.1 & 9.4 & 0.7 \\
\hline YE-8 & 7.6 & 8.0 & 6.5 & 1.5 \\
\hline YE-9 & 7.0 & 7.3 & 6.0 & 1.3 \\
\hline
\end{tabular}




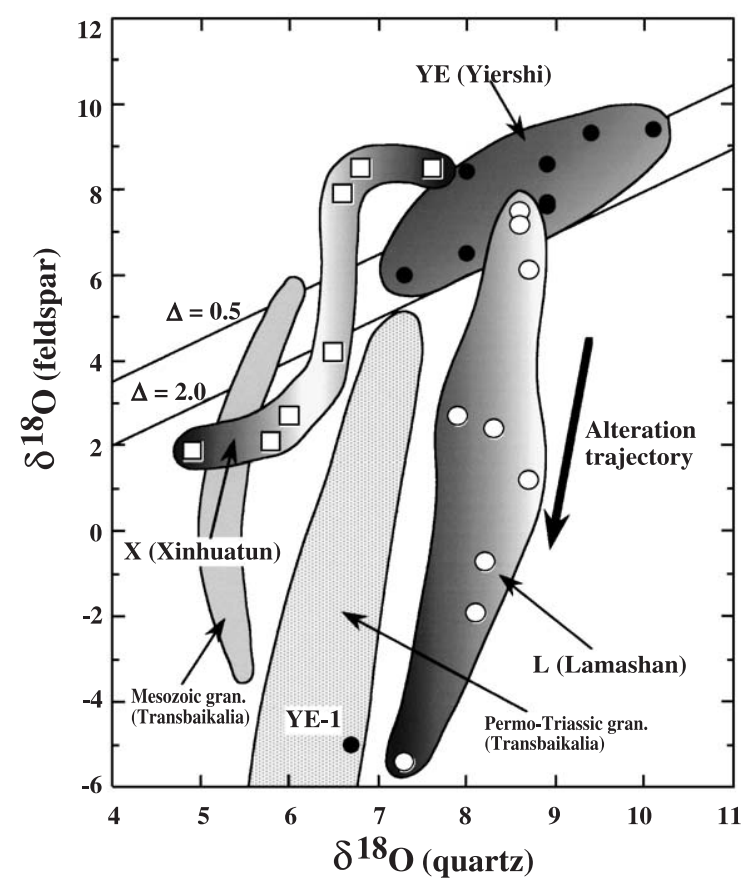

Fig. 5. Feldspar $\delta^{18} \mathrm{O}$ versus quartz $\delta^{18} \mathrm{O}$ diagram. Two lines with constant $\Delta_{\text {qz-fd }}$ values represent possible isotopic fractionations between quartz and feldspar at magmatic temperatures. Open squares: Xinhuatun pluton, open circles: Lamashan pluton, and solid circles, Yiershi pluton. Note that samples YE-1 is completely outside of the Yiershi range. The data for the rocks from Transbaikalia are from Wickham et al. (1996).

the highest $\varepsilon \operatorname{Nd}(T)$ values $(+2.1$ to +2.9$)$ among the three plutons.

\section{Tectonic implications}

Geochemical discrimination of tectonic environments for granite generation is often ambiguous and sometimes extremely controversial (Pearce et al., 1984; Maniar and Piccoli, 1989; Pearce, 1996). In the $\mathrm{Nb}$ vs. $\mathrm{Y}$ and $\mathrm{Rb}$ vs. ( $\mathrm{Y}+\mathrm{Nb}$ ) diagrams (Fig. 6), the three studied highly fractionated I-type granites of NE China fall in the volcanic-arc field of Pearce et al. (1984). According to the criteria of Sylvester (1989), however, these rocks belong to post-collisional alkaline granites. This contradiction suggests that the geochemical identification of tectonic setting is not straightforward.
For the Late Paleozoic to Mesozoic granites formed in this region, four possible tectonic settings can be hypothesized: (1) a west-dipping subduction zone of the Paleo-Pacific ocean; (2) a SE-dipping subduction zone of the Mongolia-Okhotsk ocean; (3) a post-orogenic extensional collapse of the Central Asian orogenic belt; and (4) an anorogenic setting. Usually, granites formed in subduction zones show a roughly linear distribution, which is not the case in NE China. Thus, the first two subduction mechanisms
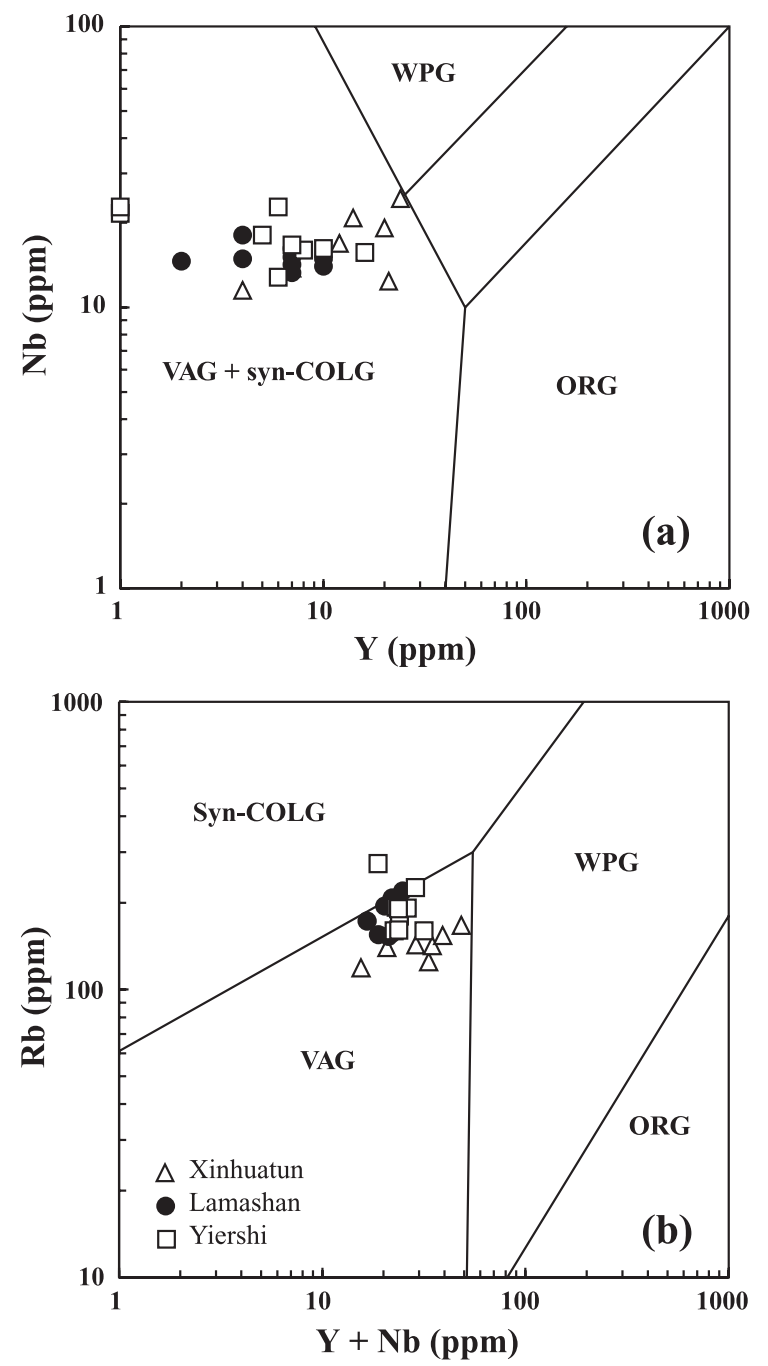

Fig. 6. Tectonic discrimination diagram of Pearce et al. (1984). Fields for Syn-COLG (Syncollisional), VAG (Volcanic arc), WPG (Within-plate) and ORG (Ocean-ridge) granites are indicated. 
are not favored. Although these granites could be formed in an anorogenic setting associated with mantle plume activity as suggested by Dobretsov and Vernikovsky (2001), this hypothesis is no longer valid due to the large range of emplacement ages and the absence of intense mafic magmatism.

Combined with the result of a study on A-type granites in this region (Wu et al., 2002), we consider that the areal distribution of granites may be related to post-orogenic extensional collapse of the Xingmeng orogenic belt. In order to account for the huge volumes of granites, we suggest that granitic formation was related to massive underplating of mafic magma in an extensional tectonic setting.

It has been shown geochemically that these granites are in marked contrast to those of the Lachlan fold belt in Australia (Gray, 1984; Chappell and White,
1992) and the Caledonian and Hercynian belts in Europe (Stephens, 1988; Pin and Duthou, 1990; Siebel et al., 1995), but are similar to Mesozoic and younger granites of the eastern Pacific Coast, such as the Canadian Cordilleran batholiths (Samson et al., 1991; Silver and Chappell, 1988), the Peninsular Range and the Sierra Nevada batholiths (DePaolo, 1981, 1988; DePaolo et al., 1991), the Andean batholiths of South America (Kay and Rapela, 1990) and the Antarctic Peninsula batholith (Pankhurst et al., 1988). Our study also suggests that the granites of NE China are difficult to be related to subduction processes for the reasons given above, but more likely to post-orogenic magmatism. Magmatic compositions have been shown to be related to tectonic setting (Pearce et al., 1984; Maniar and Piccoli, 1989; Rogers and Greenberg, 1990), but it depends more impor-

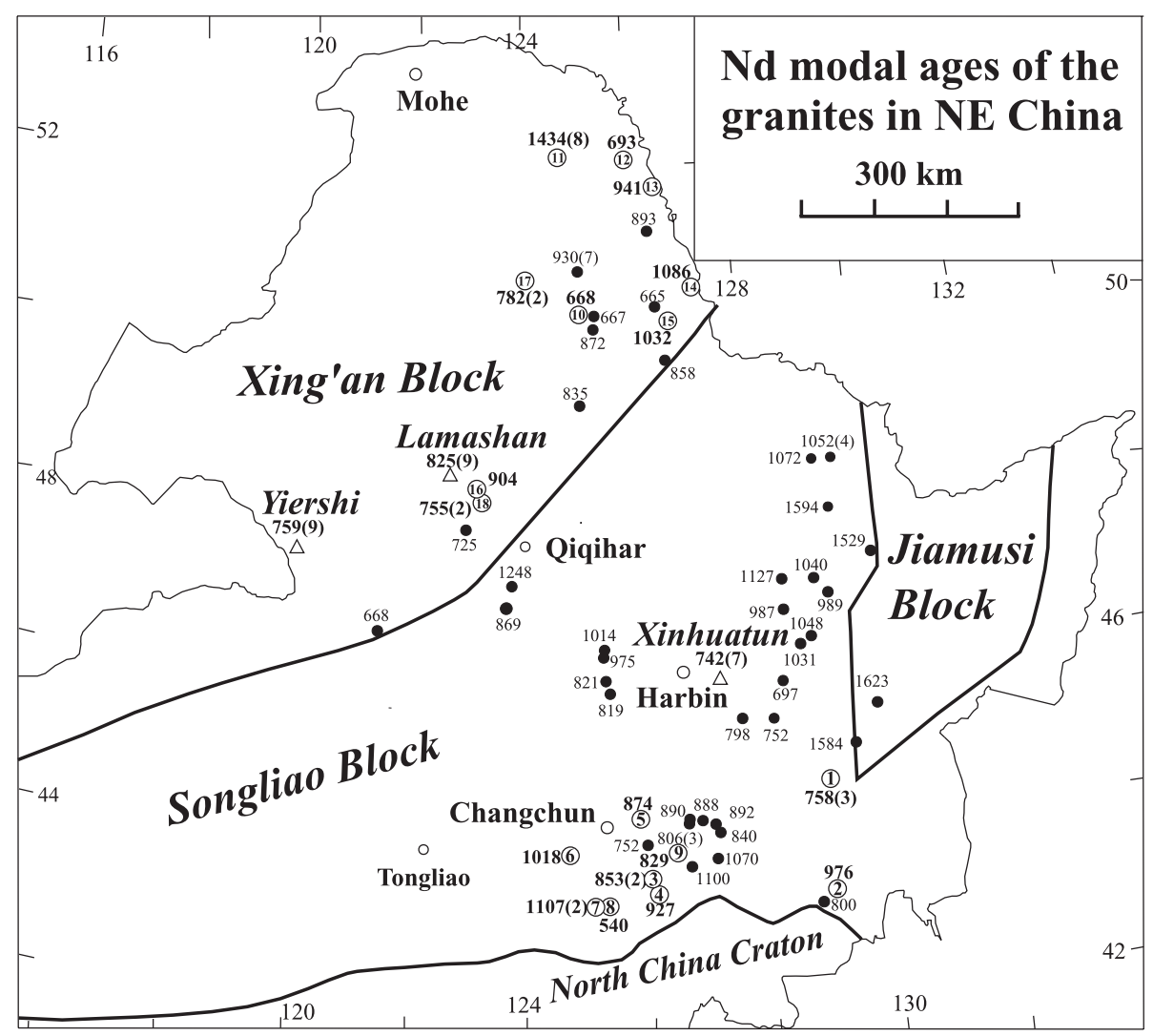

Fig. 7. Distribution of Nd model ages $\left(T_{\mathrm{DM} 2}\right)$ (in Ma) in NE China. Three triangles represent the Xinhuatun, Lamashan and Yiershi plutons. The circled numbers correspond to the sample order shown in Table 2, and the number in parentheses represents the number of samples giving the average model ages. Data source: this paper; Wu et al. (2000, 2001, 2002). 
tantly on its source rock nature and melting conditions. For example, S-type granites in the Hercynian belt of Western Europe were thought to be produced in a collisional or subduction event (Siebel et al., 1995), but other studies suggest that they were closely related to post-orogenic underplating (Downes et al., 1990; Williamson et al., 1992; Costa and Rey, 1995). A study on «subduction style» magmatism in NE Washington State, USA, also suggested that the subduction signature was inherited from the source rocks (Morris et al., 2000). Thus, attention must be paid when using the geochemical data to identify tectonic environments (e.g., Forster et al., 1997).

\section{Crustal growth}

Granite is the major component of the continental crust on Earth, hence the growth of the continent hinges much on the mode of generation of granitoids rocks. Fig. 7 summarizes the spatial distribution of $\mathrm{Sm}-\mathrm{Nd}$ model ages $\left(T_{\mathrm{DM} 2}\right)$ for the granitoids of $\mathrm{NE}$ China. The samples from the Jiamusi Block, a Proterozoic microcontinent, have much older model ages of about $1600 \mathrm{Ma}$ (Wu et al., 2000). However, in the Songliao and Xing'an Blocks, most samples show model ages younger than $1000 \mathrm{Ma}$, clearly indicating a juvenile nature of the crust in this area.

Traditionally, continental crustal growth is known to take place along continental margins by accretion of island arcs, back arc basins, and by intrusion of continental arc batholiths that comprise, in part, mantle-derived magmas (Reymer and Schubert, 1986; Rudnick, 1995). Less easy to assess is the extent of addition through underplating and intrusion of mantle-derived magmas in continental interiors during extension (Voshage et al., 1990; Hilderth et al., 1991; Coffin and Eldholm, 1994; Stein and Hofmann, 1994; Albarede, 1998; Condie, 1999; Frost et al., 2001). We argue that the formation of Phanerozoic granites in NE China was related to basaltic underplating in association with post-orogenic processes. Several petrogenetic consequences may be envisaged: (a) supply of thermal energy for promoting crustal melting, perhaps via repeated sill injection; (b) remelting the earlier underplated mafic crust via further underplating or sill injection; (c) extensive crystal fractionation leading to formation of silicic magmas; (d) assimilation of pre-existing crust, and then fractionation to more silicic magmas. Because the amounts of granitic magma generated from underplated mafic rocks by partial melting is smaller than the source itself, the amount of underplated basaltic magma should be much greater than the volume of granite. Consequently, we believe that basaltic underplating is as important a mechanism as the subduction zone processes in the growth of the continental crust.

\section{Conclusions}

The present study leads to the following conclusions:

(1) The highly fractionated I-type granites of the Xinhuatun, Lamashan and Yiershi pluton are characterized by relatively juvenile isotopic compositions: positive $\varepsilon_{\mathrm{Nd}}(T)$ values $(+2$ to +3$)$ and low $\left({ }^{87} \mathrm{Sr} /{ }^{86} \mathrm{Sr}\right)_{\mathrm{i}}(0.7045 \pm 0.0010)$. This indicates a substantial contribution of mantle material in the generation of these granites.

(2) Similar isotopic characteristics are also observed in other Paleozoic to Mesozoic granitic plutons in this area and in other parts of Central Asia. Thus, they provide strong evidence for a significant production of juvenile crust, and hence growth of the continental crust, in the Phanerozoic.

(3) $\mathrm{Sr}-\mathrm{Nd}$ and oxygen isotope data suggest that the granites were most probably derived by melting of mixed source rocks in the lower crust produced by underplating of mantle-derived magma. Tectonically, these highly fractionated I-type granites could be the result of post-orogenic magmatism. We consider that the continental growth is achieved by both lateral (arc accretion) and vertical (underplating) processes.

\section{Acknowledgements}

Fuyuan $\mathrm{Wu}$ is most grateful to the laboratory staff in Rennes, particularly to Odile Henin, Joél Macé for their instruction in chemical separation and mass spectrometry. R. Capdevila, Jon Patchett and H.-J. Forster read an earlier draft and provided many useful 
suggestions. A. Cocherie and O. T. Ramo reviewed the manuscript and helped improve the manuscript. This work was supported by the National Natural Science Foundation of China (NSFC grant 4940008 to Q. Lin and 49872031 to F.Y. Wu), the State Education Commission of China (to F.Y. Wu for his stay in France), and French research programmes of «Dynamique des Transferts Terrestres» (INSU-DTT 97) and «Cycles Géochimiques» (INSU-IT 99) granted to B.M. Jahn. This is INSU Contribution No. 337. This paper is also a contribution to IGCP-420: Crustal Growth in the Phanerozoic: Evidence from EastCentral Asia.

\section{References}

Albarede, F., 1998. The growth of continental crust. Tectonophysics 296, 1-14.

Arndt, N.T., Goldstein, S.L., 1987. Use and abuse of crust-formation ages. Geology 15, 893-895.

Chappell, B.W., White, A.J.R., 1992. I-and S-type granites in the Lachlan Fold Belt. Trans. R. Soc. Edinb.: Earth Sci. 83, 1-26.

Chen, B., Jahn, B.M., 2002a. Geochemical and isotopic studies of the sedimentary and granitic rocks of the Altai orogen of northwest China and their tectonic implications. Geol. Mag. 139, 1-13.

Chen, B., Jahn, B.M., 2002b. Genesis of post-collisional granitoids and basement nature of the Junggar Terrane, NW China: Nd-Sr isotope and trace element evidence. J. Asian Earth Sci. (submitted for publication).

Chen, B., Jahn, B.M., Wilde, S., Xu, B., 2000. Two constrasting Paleozoic magmatic belts in northern Inner Mongolia, China: petrogenesis and tectonic implications. Tectonophysics 328, $157-182$.

Chiba, H., Chacko, T., Clayton, R.N., Goldsmith, J.R., 1989. Oxygen isotope fractionations involving diopside, forsterite, magnetite and calcite: application to geothermometry. Geochim. Cosmochim. Acta 53, 2985-2995.

Clayton, R.N., Mayeda, T.K., 1963. The use of bromine pentafluoride in the extraction of oxygen from oxides and silicates for isotopic analysis. Geochim. Cosmochim. Acta 27, 43-52.

Coffin, M.A., Eldholm, O., 1994. Large igneous provinces: crustal structure, dimensions, and external consequences. Rev. Geophys. $32,1-36$.

Condie, K.C., 1999. Mafic crustal xenoliths and the origin of the lower continental crust. Lithos 46, 95-101.

Costa, S., Rey, P., 1995. Lower crystal rejuvenation and growth during post-thickening collapse: insights from a crustal cross section through a Variscan metamorphic core complex. Geology 23, 905-908.

Criss, R.E., Taylor Jr., H.P., 1986. Meteoric-hydrothermal systems. In: Valley, J.W., Taylor Jr., H.P., O’Neill, J.R. (Eds.), Stable Isotopes in High Temperature Geological Processes. Mineral. Soc. Am. Rev. Mineral., vol. 16, pp. 373-424.
DePaolo, D.J., 1981. A neodymium and strontium isotopic study of the Mesozoic calc-alkaline granitic batholiths of the Sierra Nevada and Peninsular Ranges, California. J. Geophys. Res. 86, $10470-10488$.

DePaolo, D.J., 1988. Age dependence of the composition of continental crust: evidence from $\mathrm{Nd}$ isotopic variations in granitic rocks. Earth Planet. Sci. Lett. 90, 263-271.

DePaolo, D.J., Linn, A.M., Schubert, G., 1991. The continental crustal age distribution: methods of determining mantle separation ages from $\mathrm{Sm}-\mathrm{Nd}$ isotopic data and application to the southeastern United States. J. Geophys. Res. 96, 2071-2088.

Dobretsov, N.L., Vernikovsky, V.A., 2001. Mantle plumes and their geologicl manifestations. Inter. Geol. Rev. 43, 771-787.

Downes, H., Dupuy, C., Leyreloup, A.F., 1990. Crustal evolution of the Hercynian belt of the Western Europe: evidence from lowercrustal granulitic xenoliths (French Massif Central). Chem. Geol. 83, 209-231.

Forster, H.J., Tischendorf, G., Trumbull, R.B., 1997. An evaluation of the $\mathrm{Rb}-(\mathrm{Y}+\mathrm{Nb})$ discrimination diagram to infer tectonic setting of silicic igneous rocks. Lithos 40, 261-293.

Frost, C.D., Bell, J.M., Frost, B.R., Chamberiain, K.R., 2001. Crustal growth by magmatic underplating: isotopic evidence from the northern Sherman batholith. Geology 29, 515-518.

Gregory, R.T., Criss, R.E., 1986. Isotope exchange in open and closed systems. In: Valley, J.W., Taylor Jr., H.P., O’Neill, J.R. (Eds.), Stable Isotopes in High Temperature Geological Processes. Mineral. Soc. Am. Rev. Mineral., vol. 16, pp. 91-127.

Gregory, R.T., Criss, R.E., Taylor, H.P., 1989. Oxygen isotope exchange kinetics of mineral pairs in closed and open system: applications to problems of hydrothermal alteration of igneous rocks and Precambrian iron formations. Chem. Geol. 75, 1-42.

Gray, C.M., 1984. An isotopic mixing model for the origin of granitic rocks in southeastern Australia. Earth Planet. Sci. Lett. 70, 47-60.

Han, B.F., Wang, S.G., Jahn, B.M., Hong, D.W., Kagami, H., Sun, Y.L., 1997. Depleted-mantle magma source for the Ulungur River A-type granites from north Xinjiang, China: geochemistry and $\mathrm{Nd}-\mathrm{Sr}$ isotopic evidence, and implication for Phanerozoic crustal growth. Chem. Geol. 138, 135-159.

Heinhorst, J., Lehmann, B., Ermolov, P., Serykh, V., Zhurutin, S., 2000. Paleozoic crustal growth and metallogeny of Central Asia: evidence from magmatic-hydrothermal ore systems of Central Kazakhstan. Tectonophysics 328, 69-87.

Hilderth, W., Halliday, A.N., Christiansen, R.L., 1991. Isotopic and chemical evidence concerning the genesis and contamination of basaltic and rhyolitic magma beneath the Yellowstone plateau volcanic field. J. Petrol. 32, 63-138.

Hu, A.Q., Jahn, B.M., Zhang, G.X., Chen, Y.B., Zhang, Q.F., 2000. Crustal evolution and Phanerozoic crustal growth in northern Xinjiang: Nd isotopic evidence: Part I. Isotopic characterization of basement rocks. Tectonophysics 328, 15-51.

Jahn, B.M., 2002. Generation of the juvenile crust in the Central Asian Orogenic Belt. In: Wu, F.Y., Wilde, S.A., Jahn, B.M. (Eds.), IGCP-420 4th Workshop Abstracts and Excursion Guidebook, Changchun, China, pp. 57-68.

Jahn, B.M., Condie, K.C., 1995. Evolution of the Kaapvaal Craton as viewed from geochemical and $\mathrm{Sm}-\mathrm{Nd}$ isotopic anal- 
yses of intracratonic pelites. Geochim. Cosmochim. Acta 59, 2239-2258.

Jahn, B.M., Zhou, X.H., Li, J.L., 1990. Formation and tectonic evolution of southeastern China and Taiwan: isotopic and geochemical constraints. Tectonophysics 183, 145-160.

Jahn, B.M., Cornichet, J., Cong, B.L., Yui, T.F., 1996. Ultrahigh$\varepsilon_{\mathrm{Nd}}$ eclogites from an ultrahigh-pressure metamorphic terrane of China. Chem. Geol. 127, 61-79.

Jahn, B.M., Wu, F.Y., Hong, D.W., 2000a. Important crustal growth in the Phanerozoic: isotopic evidence of granitoids from East-central Asia. Proc. Indian Acad. Sci., Earth Planet. Sci. $109,5-20$.

Jahn, B.M., Wu, F.Y., Chen, B., 2000b. Massive granitoid generation in Central Asia: Nd isotope evidence and implication for continental growth in the Phanerozoic. Episodes 23, 82-92.

Jahn, B.M., Wu, F.Y., Chen, B., 2000c. Granitoids of the Central Asian Orogenic Belt and continental growth in the Phanerozoic. Trans. R. Soc. Edinb.: Earth Sci. 91, 181-193.

Jahn, B.M., Wu, F.Y., Capdevila, R., Fourcade, S., Wang, Y.X., Zhao, Z.H., 2001. Highly evolved juvenile granites with tetrad REE patterns: the Woduhe and Baerzhe granites from the Great Xing'an (Khingan) Mountains in NE China. Lithos 59, $171-198$.

Kay, S.M., Rapela, C.W. (Eds.), 1990. Plutonism from Antarctica to Alaska. Am. Geol. Soc. Spec. Paper, vol. 241. 263 pp.

Keto, L.S., Jacobsen, S.B., 1987. Nd and Sr isotopic variations of Early Paleozoic oceans. Earth Planet. Sci. Lett. 84, 27-41.

Kovalenko, V.I., Yarmolyuk, V.V., Kovach, V.P., Kotov, A.B., Kozakov, I.K., Sal'nikova, E.B., 1996. Sources of Phanerozoic granitoids in Central Asia: $\mathrm{Sm}-\mathrm{Nd}$ isotope data. Geochem. Int. 34, 628-640.

Maniar, P.D., Piccoli, P.M., 1989. Tectonic discrimination of granitoids. Geol. Soc. Am. Bull. 101, 635-643.

Morris, G.A., Larson, P.B., Hooper, P.R., 2000. "Subduction style" magmatism in a non-subduction setting: the Colville igneous complex, NE Washington State, USA. J. Petrol. 41, 43-67.

Pankhurst, R.J., Hole, M.J., Brook, M., 1988. Isotope evidence for the origin of Andean granites. Trans. R. Soc. Edinb.: Earth Sci. 79, $123-133$.

Pearce, J.A., 1996. Sources and settings of granitic rocks. Episodes 19, $120-125$.

Pearce, J.A., Harris, N.B.W., Tindle, A.G., 1984. Trace element discrimination diagrams for the tectonic interpretation of granitic rocks. J. Petrol. 25, 956-983.

Pin, C., Duthou, J.L., 1990. Sources of Hercynian granitoids from the French Massif Central: inferences from $\mathrm{Nd}$ isotopes and consequences for crustal evolution. Chem. Geol. 83, 281-296.

Reymer, A., Schubert, G., 1986. Rapid growth of some major segments of continental crust. Geology 14, 299-302.

Rogers, J.J.W., Greenberg, J.E., 1990. Late-orogenic, post-orogenic, and anorogenic granites: distinction by major-element and trace-element chemistry and possible origins. J. Geol. 98, $291-310$.

Rudnick, R.L., 1995. Making continental crust. Nature 378, 571-578.

Samson, S.D., McClelland, W.C., Patchett, P.J., Gehrels, G.E., Anderson, R.G., 1989. Evidence from neodymium isotopes for mantle contributions to Phanerozoic crustal genesis in the Canadian Cordillera. Nature 337, 705-709.

Samson, S.D., Patchett, P.J., McClelland, W.C., Gehrels, G.E., 1991. Nd and $\mathrm{Sr}$ isotopic constraints on the petrogenesis of the west side of the northern Ciast Mountain batholith, Alaskan and Canadian Cordillera. Can. J. Earth Sci. 28, 939-946.

Sengör, A.M.C., Natal'in, B.A., 1996a. Paleotectonics of Asia: fragments of a synthesis. In: Yin, A., Harrison, M. (Eds.), The Tectonic Evolution of Asia. Cambridge Univ. Press, New York, pp. 486-640.

Sengör, A.M.C., Natal'in, B.A., 1996b. Turkic-type orogeny and its role in the making of the continental crust. Annu. Rev. Earth Planet. Sci. 24, 263-337.

Sengör, A.M.C., Natal'in, B.A., Burtman, V.S., 1993. Evolution of the Altaid tectonic collage and palaeozoic crustal grouth in Eurasia. Nature 364, 299-307.

Sheppard, S.M.F., 1986. Igneous rocks: III. Isotopic case studies of magmatism in Africa, Eurasia and oceanic islands. In: Valley, J.W., Taylor Jr., H.P., O’Neill, J.R. (Eds.), Stable Isotopes in High Temperature Geological Processes. Mineral. Soc. Am. Rev. Mineral., vol. 16, pp. 319-371.

Siebel, W., Höhndorf, A., Wendt, I., 1995. Origin of late Variscan granitoids from NE Bavaria, Germany, examplified by REE and Nd isotope systematics. Chem. Geol. 125, 249-270.

Silver, L.T., Chappell, B.W., 1988. The Peninsular Range batholith: an insight into the evolution of the Cordilleran batholiths of southeastern North America. Trans. R. Soc. Edinb.: Earth Sci. $79,105-121$.

Stein, M., Hofmann, A.W., 1994. Mantle plumes and episodic crustal growth. Nature 372, 63-68.

Stephens, W.E., 1988. Granitoid plutonism in the Caledonian orogen of Europe. In: Harris, A.L., Fettes, D.J. (Eds.), The Caledonian-Appalachian Orogen. Geol. Soc. Spec. Publ., vol. 38, pp. 389-404.

Sylvester, P.J., 1989. Post-collisional alkaline granites. J. Geol. 97, 261-280.

Voshage, H., Hoffman, A.W., Mazzucchelli, M., Rivalenti, G., Sinigoi, S., Raczek, I., Demarchi, G., 1990. Isotopic evidence from the Ivrea Zone for a hybrid lower crust formed by magmatic underplating. Nature 347, 731-736.

Wickham, S.M., Alberts, A.D., Zanvilevich, A.N., Litvinovsky, B.A., Bindeman, I.N., Schauble, E.A., 1996. A stable isotope study of anorogenic magmatism in East Central Asia. J. Petrol. 37, $1063-1095$.

Williamson, B.J., Downes, H., Thirlwall, M.F., 1992. The relationship between crustal magmatic underplating and granite genesis: an example from the Velay granite complex, Massif Central, France. Trans. R. Soc. Edinb.: Earth Sci. 83, 235-245.

Wu, F.Y., Jahn, B.M., Lin, Q., 1998. Isotopic characteristics of the postorogenic granite in orogenic belt of northern China and their implications in crustal growth. Chin. Sci. Bull. 43, $420-424$.

Wu, F.Y., Jahn, B.M., Wilde, S., Sun, D.Y., 2000. Phanerozoic crustal growth: $\mathrm{U}-\mathrm{Pb}$ and $\mathrm{Sr}-\mathrm{Nd}$ isotopic evidence from the granites in northeastern China. Tectonophysics 328, 89-113.

Wu, F.Y., Sun, D.Y., Li, H.M., Wang, X.L., 2001. The nature of basement beneath the Songliao Basin in NE China: geochem- 
ical and isotopic constraints. Phys. Chem. Earth (part A) 26, 793-803.

Wu, F.Y., Sun, D.Y., Li, H.M., Jahn, B.M., Wilde, S.A., 2002. Atype granites in Northeastern China: age and geochemical constraints on their petrogenesis. Chem. Geol. 187, 143-173.

Wu, F.Y., Jahn, B.M., Lo, C.H., Yui, T.F., Lin, Q., Ge, W.C., Sun,
D.Y., 2003. Highly fractionated I-type granites in NE China (I): geochronology and petrogenesis. Lithos 66, 241-273.

Zhao, Z.H., Bai, Z.H., Xiong, X.L., Mei, H.J., Wang, Y.X., 2000. Geochemistry of alkali-rich igneous rocks of northern Xinjiang and its implications for geodynamics. Acta Geol. Sin. $74,321-328$. 